\title{
Microbiological Quality of Traditionally Smoked Fish from Lake Victoria Crescent, Uganda
}

\author{
Rubaijaniza Abigaba $^{1 *} \quad$ Jessica L. Nakavuma ${ }^{1} \quad$ Clovice Kankya $^{2} \quad$ John D. Kabasa ${ }^{2}$ \\ 1.Department of Biomolecular and Biolab Sciences, Makerere University, P. O. Box 7062, Kampala, Uganda \\ 2.Department of Biosecurity, Ecosystem and Veterinary Public Health, Makerere University, P. O. Box 7062, \\ Kampala, Uganda
}

\begin{abstract}
Microbiological quality of traditionally smoked fish was assessed to ascertain the effectiveness of traditional smoking process and handling conditions for smoked fish shelf-life and safety. Fish smoking is a popular preservation method in Uganda. Although fish smoking is a widely used method of preservation, the presence of spoilage and pathogenic bacteria in smoked fish and food borne illnesses remain a threat in developing countries. However, little is known about microbial quality of fish smoked from Uganda. In light of this, the status of spoilage, hygiene and pathogenic indicator organisms in fish (Nile perch) was investigated. A total of 75 randomly selected fresh, freshly smoked, and on shelf smoked fish from landing sites and markets respectively, were obtained for microbial and moisture content analysis. Descriptive statistics was used to present the data, while ANOVA and Tukey tests were used to analyze the data. The study revealed that, the smoking process significantly $(\mathrm{P}<0.05)$ reduced microbial load in freshly fish to levels acceptable for consumption, despite the high levels of moisture content in the range of $59.2 \%$ to $66.5 \%$. The mean microbial load (log of $\mathrm{cfu} / \mathrm{g}$ ) of indicator organisms for samples from different sites varied from; 9.97 to $10.18 ; 7.39$ to 8.19 (aerobic mesophilic bacteria or TPC), 5.18 to $5.27 ; 0$ to 4.28 (total coliforms), 2.73 to $5.55 ; 0$ to 0.85 (E. coli), 4.97 to $7.32 ; 0$ to 3.11 (S. aureus), and 2.21 to $4.56 ; 0$ to 0.82 (Yeasts and molds), for fresh and smoked fish samples respectively. Additionally, mean microbial load for on shelf smoked fish from markets varied from; 8.2 to 10.57 (TPC), 2.8-6.63 (total coliforms), 0 to 6.11 (E. coli), 6.74 to 8.89 (S. aureus), and 0 to 5.51 (Yeasts and molds). Although findings showed that, traditional fish smoking was somewhat effective in reducing microbial load to acceptable levels, the microbial status of on shelf smoked fish indicated poor fish handling and storage. Therefore, proper fish handling during and post-smoking as well as cooking before consumption, are highly recommended for assured shelf-life and safety of smoked fish for consumption in Uganda.
\end{abstract}

Keywords: Microbiological, quality, smoked fish, Uganda, indicator organisms

DOI: $10.7176 /$ FSQM/104-05

Publication date: January $31^{\text {st }} 2021$

\section{Introduction}

Fish is a valuable resource because it is a source of cheap proteins, long chain $\mathrm{n} 3$ polyunsaturated fatty acids (LCn3PUFAs), and foreign exchange (Kleter, 2004; FAO/WHO, 2011) especially in developing countries (Egbal et al., 2010). However, this food commodity is highly perishable, a factor that greatly affects its shelf-life and consumer safety. Fish perishability is attributed to its richness in essential nutrients that aid proliferation of microbes (Olaleye \& Abegunde, 2015). Hence, fish would easily be rendered unfit for consumption within about a day after capture, unless its subjected to some form of preservation (Abolagba \& Uwagbai, 2011). In light of this, various preservation methods such as smoking, sun drying, salting, freezing, and deep frying have been used to prolong the shelf-life of fish in many countries (Egbal et al., 2010; Olaleye \& Abegunde, 2015). Despite the existence of various preservations methods, most fish and other freshwater catch is consumed in smoked form. It is noteworthy that, practically all species of fish in most countries can be smoked (Adeyeye \& Oyewole, 2016). Furthermore, fish smoking is the most preferred preservation method, because it imparts a desirable flavor and inhibits microbial growth, and thus prolongs shelf-life of smoked fish (Kumolu-Johnson et al., 2009; Abolagba \& Uwagbai, 2011). Coincidentally, this method is the most widely used for preserving fish in Uganda, with Nile perch (Lates niloticus) and Tilapia (orechromis niloticus) fish species, being the frequently smoked by artisanal processors (Kabahenda et al., 2009; Abigaba et al., 2020).

Although fish smoking can destroy pathogens and spoilage organisms rendering smoked fish safe for consumption (Tzouros \& Arvanitoyannis, 2000), some form of loss and spoilage can still occur especially with artisan processing or poor post-harvest technology (Kumolu-Johnson et al., 2009; Abolagba \& Uwagbai, 2011). Accordingly, the smoking method, the technique adopted and handling practices certainly influence both microbial safety and shelf-life of smoked fish (Salaudeen \& Osibona, 2018; Tzouros \& Arvanitoyannis, 2000). In view of this, high bacterial and mycofloral load in smoked fish beyond acceptable limits, have been reported in some countries. Their presence poses potential health hazards to smoked fish consumers, but also, compromises products' shelf-life (Adeyeye \& Oyewole, 2016). Compromised shelf-life impacts on the availability of this cheap protein source for many consumers particularly the remote resource-poor population. Additionally, considering reports of 
high spoilage and pathogenic microbial load in smoked fish from different countries, there was need to ascertain microbiological status of traditionally smoked fish from Uganda where information about the same, was largely scanty. Hence, this study was carried out in order to assess the microbial quality of fish smoked as a tool for surveying the effectiveness of traditional smoking process and the handling conditions, and measure of the shelflife and safety of smoked fish consumed locally.

\section{Materials and Methods \\ 2.1 Study design and location}

The study was carried out from Lake Victoria crescent of Uganda. Lake Victoria is the most important source of inland fishery production for human food and fishmeal industry. It is situated in East Africa, within $0^{\circ} 20^{\prime} \mathrm{N}$ to $3^{\circ} 00^{\prime} \mathrm{S}$ and $31^{\circ} 39^{\prime} \mathrm{E}$ to $34^{\circ} 53^{\prime} \mathrm{E}$, at an altitude of $1134 \mathrm{~m}$, and surface area of $68800 \mathrm{~km}^{2}$ (Njiru et al., 2008). Although Uganda's crescent of the Lake is approximately 43\% (Njiru et al., 2008), it contributes the largest proportion of the total national catch (UIA, 2009). Hence, the study area was considered based on; fish catch, popularity of the artisanal fish smoking technology among local fishing communities, market significance of smoked fish at the local and regional levels, and consumer base. For this study, a survey on quality of fish traditionally smoked from Lake Victoria, was carried out using fish samples obtained from; landing sites of Katosi, Kasenyi, and Ggaba (in Mukono, Wakiso, and Kampala districts respectively) and major markets of Bwaise, Nakulabye and Owino from Kampala district. Both processors of smoked fish and retailers were purposively selected based on their willingness to participate in the study and quantity of fish possessed.

\subsection{Moisture content and fish smoking temperature determination}

As part of evaluation for effectiveness of traditional fish smoking, moisture content of freshly smoked fish was measured to supplement the findings from the microbiological tests. Accordingly, moisture content for freshly smoked fish was obtained based on procedure by Swastawati, (2008). Briefly, approximately $5 \mathrm{~g}$ of fish sample was measured using a weighing balance (Sartorius AG, Gottingen/Germany) before heating and the weight was recorded as W2 (wet weight). This was followed by heating in an air oven (WTB-Binder, Tuttlingen/Germany) at $105^{\circ} \mathrm{C}$ for 24 hours to obtain W2 (dry weight), measured after cooling in a desiccator. Using the formula (1) below, moisture content for freshly smoked fish samples were calculated;

$$
\% \text { moisture content }=\left(\frac{W 2-W 3}{W 2}\right) \times 100
$$

\subsection{Microbiological analysis}

\subsubsection{Sampling and sample size}

For microbiological analysis, five sample units (fish samples) were obtained from every processor according to established sampling plan (ICMSF, 1986). Accordingly, a total of 60 fresh and freshly smoked fish samples were obtained from processors. Additionally, a total of 15 smoked fish samples were randomly obtained from the markets for microbiological evaluation. The indicator organisms considered included; aerobic mesophilic bacteria, total coliforms, Escherichia coli (E. coli), Staphylococcus aureus (S. aureus), as well as yeasts and molds. All samples were aseptically and randomly selected from top, sides, middle and bottom of sampled lots, and immediately transported in sterile polythene bags on ice $\left(0^{\circ} \mathrm{C}\right)$, to Makerere University laboratory for analysis.

\subsubsection{Sample preparation and analysis}

Sample preparation for microbiological analysis was done according to International Commission of Microbiological Specifications for Food (ICMSF, 1978). While ensuring asepsis, fish samples were removed from sterile bags and portions excised from different parts including the skin and muscle. Approximately $25 \mathrm{~g}$ was added to $225 \mathrm{ml}$ of $0.1 \%$ sterile peptone water (Laboratorios conda, South Africa) in sterile stomacher bags for homogenization in a stomacher (Kalyx Biosciences Inc., Canada) at 12000 revolutions/minute for 1-2 minutes. A ten-fold serial dilutions of $1 \mathrm{ml}$ of homogenate was also done for all samples up to $10^{-5}$. The aerobic mesophilic bacteria load (Total Plate Count) was obtained by inoculation of dilutions including homogenate $\left(10^{\circ}\right)$ on plate count agar (PCA, Himedia, India) using pour plate method (FAO, 1992). Inoculated plates were incubated at $37^{\circ} \mathrm{C}$ for 24 hours, followed by calculation of counts for a plate with a dilution between 30-300 colonies to obtain microbial numbers per gram of a sample. On the other hand, $S$. aureus enumeration was carried out using surface spread method, and its confirmation was done using coagulase test (FAO, 1992). Briefly, inoculation of homogenate $(0.25 \mathrm{ml})$ and dilutions up to $10^{-5}$ on Baird-Parker agar (Himedia, India) was done. Inoculated samples were incubated at $37^{\circ} \mathrm{C}$ for $24-48$ hours, followed by selection of dilutions giving between $20-200$ colonies for establishing the presumptive $S$. aureus load. For total coliforms and E. coli load, parallel tests were made using same prepared samples. Both homogenate and dilutions were inoculated on Violet Red Bile Agar (VRBA, Himedia, India) medium by pour plating and then incubated at $37^{\circ} \mathrm{C}$ for $24-48$ hours. Pink colonies were counted on a dilution giving 30-300 colonies for calculation of total coliform load. The similar inoculated dilutions were instead incubated at $45^{\circ} \mathrm{C}$ for $24-48$ hours on VRBA and pink colonies counted to estimate E. coli load (Harrigan, 1998). 
While the enumeration of mycoflora (yeast and molds) enumeration was done using surface spread method (Harrigan, 1998). Accordingly, inoculation of the organism was done on Potato Dextrose agar (PDA, Laboratorios conda, South Africa), followed by incubation at $28^{\circ} \mathrm{C}$ for $72-120$ hours, and then plates observed for fungal colony growth. The number of colonies counted was used to calculate mycofloral load. It is noteworthy that, sample inoculations for all the tests were done in duplicate.

\subsection{Data analysis}

Microbiological data from laboratory was summarized using excel 2007 software in form of means and standard deviation (SD). Descriptive statistics was used to present data in form of tables. In addition, data in excel was exported to SPSS software for windows to analyze mean microbial differences using one-way ANOVA. Wherever differences were indicated, Tukey's-test was used to obtain source of observed differences.

\section{Results}

\subsection{Mean microbial load for fresh and smoked fish}

The mean microbial counts (log of $\mathrm{cfu} / \mathrm{g}$ ) and corresponding standard deviations (SD) for both fresh and smoked fish samples are shown below (Table 1). From study findings, mean microbial load in fresh fish samples was highest for Kasenyi, followed by Ggaba, and then Katosi landing sites. Furthermore, the study revealed that, smoking process reduced microbial load significantly $(\mathrm{P}<0.05)$, with exception of ECC for Katosi, and Yeasts and molds for Ggaba landing sites.

Table 1: Mean microbial load of fresh and smoked fish from landing sites

\begin{tabular}{lllllll}
\hline Mircobial & \multicolumn{2}{c}{ Ggaba } & \multicolumn{2}{c}{ Kasenyi } & \multicolumn{2}{c}{ Katosi } \\
\cline { 2 - 6 } Parameter & Fresh & Smoked & Fresh & Smoked & Fresh & Smoked \\
\hline TPC & $10.18 \pm 0.55^{\mathrm{a}}$ & $8.19 \pm 0.92^{\mathrm{b}}$ & $10.17 \pm 0.41^{\mathrm{c}}$ & $7.70 \pm 0.95^{\mathrm{d}}$ & $9.97 \pm 0.33^{\mathrm{b}}$ & $7.39 \pm 1.41^{\mathrm{c}}$ \\
TCC & $5.27 \pm 0.61^{\mathrm{a}}$ & $0^{\mathrm{b}}$ & $5.87 \pm 0.18^{\mathrm{c}}$ & $4.28 \pm 0.64^{\mathrm{d}}$ & $5.18 \pm 0.89^{\mathrm{b}}$ & $2.91 \pm 0.13^{\mathrm{c}}$ \\
ECC & $4.06 \pm 1.54^{\mathrm{a}}$ & $0^{\mathrm{b}}$ & $5.55 \pm 0.37^{\mathrm{c}}$ & $0.9 \pm 0.5^{\mathrm{d}}$ & $2.73 \pm 0.41^{\mathrm{b}}$ & $0.85 \pm 0.59^{\mathrm{b}}$ \\
STAPH & $6.15 \pm 0.50^{\mathrm{a}}$ & $0^{\mathrm{b}}$ & $7.32 \pm 0.58^{\mathrm{c}}$ & $3.11 \pm 1.18^{\mathrm{d}}$ & $4.97 \pm 0.74^{\mathrm{b}}$ & $0^{\mathrm{c}}$ \\
Y\&M & $2.21 \pm 0.35^{\mathrm{a}}$ & $0.82 \pm 0.42^{\mathrm{a}}$ & $4.56 \pm 0.37^{\mathrm{c}}$ & $0.4 \pm 0.26^{\mathrm{d}}$ & $4.50 \pm 0.25^{\mathrm{b}}$ & $0^{\mathrm{c}}$ \\
\hline
\end{tabular}

Key: Different superscripts (letters) in the same row, show that mean values are significantly different $(\mathrm{P}<0.05)$

TPC: Total Plate Count

TCC: Total Coliforms Count

ECC: E. coli count

STAPH: S. aureus

Y\&M: Yeasts and molds

\subsection{Microbial load of freshly smoked fish and corresponding acceptable limits}

From study findings (Table 2), samples from Kasenyi had the highest microbial load for all indicator organisms, most of which except for TPC as well as Yeasts and molds were above acceptable limits. Furthermore, samples from other sites had counts within acceptable limits except for TPC. Furthermore, moisture content for all samples was way higher than acceptable limits for smoked-dried fish.

Table 2: Mean microbial load of freshly smoked fish and acceptable limits

\begin{tabular}{lllll}
\hline Parameter & $\begin{array}{l}\text { Ggaba } \\
(\log \text { of cfu/g) }\end{array}$ & $\begin{array}{l}\text { Kasenyi } \\
(\log \text { of cfu/g) }\end{array}$ & $\begin{array}{l}\text { Katosi } \\
(\log \text { of cfu/g) }\end{array}$ & $\begin{array}{l}\text { Recommended } \\
(\log \text { of cfu/g) }\end{array}$ \\
\hline TPC & $8.19 \pm 0.92^{\mathrm{a} *}$ & $7.70 \pm 0.95^{\mathrm{ab} *}$ & $7.39 \pm 1.41^{\mathrm{b} *}$ & $\mathbf{6 - < 7}$ \\
TCC & $0^{\mathrm{a}}$ & $4.28 \pm 0.64^{\mathrm{b} *}$ & $2.91 \pm 0.13^{\mathrm{b}}$ & $\mathbf{2}-<\mathbf{4}$ \\
ECC & $0^{\mathrm{a}}$ & $0.9 \pm 0.5^{\mathrm{a}}$ & $0.85 \pm 0.59^{\mathrm{a}}$ & $\mathbf{1 . 3}-<\mathbf{2}$ \\
STAPH & $0^{\mathrm{b}}$ & $3.11 \pm 1.18^{\mathrm{c} *}$ & $0^{\mathrm{b}}$ & $\mathbf{1 . 3 - > \mathbf { 2 }}$ \\
Y\&M & $0.82 \pm 0.42^{\mathrm{a}}$ & $0.4 \pm 0.26^{\mathrm{a}}$ & $0^{\mathrm{a}}$ & $<\mathbf{4}$ \\
Moisture $(\%)$ & $59.2-61.0^{*}$ & $60.2-63.7^{*}$ & $63.8-66.5^{*}$ & $\mathbf{1 2}$ \\
\hline
\end{tabular}

Key: $\quad$ Mean values with different superscripts (letters) in the same row, are significantly different, $(\mathrm{P}<0.05)$

Values with symbol * are above recommended limits

TPC: Total plate count $\quad$ TCC: Total Coliform count $\quad$ ECC: E. coli count

STAPH: $S$. aureus $\quad$ Y\&M: Yeasts and molds

3.3 Mean microbial load of smoked fish from market

The study findings (Table 3) show the microbial status (Mean SD) of smoked fish sold from Kampala markets. Evidently, microbial load in all samples except for Yeast and molds (Owino), as well as ECC and Yeast and molds (Nakulabye) were above the acceptable limits. 
Table 3: Mean microbial load of smoked fish from the markets

\begin{tabular}{lllll}
\hline $\begin{array}{l}\text { Microbial } \\
\text { Parameter }\end{array}$ & $\begin{array}{l}\text { Nakulabye } \\
(\log \text { of cfu/g) }\end{array}$ & $\begin{array}{l}\text { Bwaise } \\
(\log \text { of cfu/g) }\end{array}$ & $\begin{array}{l}\text { Owino } \\
(\log \text { of cfu/g) }\end{array}$ & $\begin{array}{l}\text { Recommended } \\
(\log \text { of cfu/g) }\end{array}$ \\
\hline TPC & $8.20 \pm 1.02^{\mathrm{a}^{*}}$ & $10.57 \pm 0.28^{\mathrm{b}^{*}}$ & $8.40 \pm 1.56^{\mathrm{a}^{*}}$ & $\mathbf{6 - < 7}$ \\
TCC & $2.80 \pm 0.59^{\mathrm{a}}$ & $6.63 \pm 1.11^{\mathrm{b}^{*}}$ & $3.34 \pm 1.41^{\mathrm{a}^{*}}$ & $\mathbf{2 - < \mathbf { 4 }}$ \\
ECC & $0^{\mathrm{a}}$ & $6.11 \pm 1.17^{\mathrm{b}^{*}}$ & $1.59 \pm 0.56^{\mathrm{a}^{*}}$ & $\mathbf{1 . 3 - < 2}$ \\
STAPH & $7.26 \pm 0.59^{\mathrm{a}^{*}}$ & $8.89 \pm 0.27^{\mathrm{c}^{*}}$ & $6.74 \pm 1.10^{\mathrm{a}^{*}}$ & $\mathbf{1 . 3}->\mathbf{2}$ \\
Y\&M & $0^{\mathrm{b}}$ & $5.51 \pm 0.48^{\mathrm{a}^{*}}$ & $2.84 \pm 0.66^{\mathrm{a}}$ & $<\mathbf{4}$ \\
\hline
\end{tabular}

Key: $\quad$ Mean values with different superscripts (letters) in the same row, are significantly different, $(\mathrm{P}<0.05)$ Values with symbol * are above recommended limits TPC: Total plate count $\quad$ TCC: Total Coliforms Count $\quad$ ECC: E. coli count STAPH: $S$. aureus $\quad$ Y\&M: Yeasts and molds

\section{Discussion}

Smoking involves heat application to remove water, and inhibit microbial and enzymatic actions on fish (KumoluJohnson et al., 2010). According to Tzouros \& Arvanitoyannis, (2000), the microbial stability in smoked fish depends on; salt level after brining, amount of heat applied (hot-smoking), the inhibitory actions of some smoke components, and the dehydrating effect of hot-smoking. From the study, moisture content somewhat reduced due to heating with the lowest value at 59.2\%. However, even the lowest value achieved this was still higher than recommended 12\% (Plahar et al., 1999) for smoke-dried fish if a longer shelf-life is desired. Unsurprisingly, similar results were reported by Egbal et al., (2010) in Sudan, because hot smoking technique used involves heating for a few hours which can hardly reduce the moisture content to as low as $12 \%$. The high moisture content was presumed to favor microbial proliferation considering the water of activity effect on their growth. Accordingly, it was presumed that hot-smoked fish was still vulnerable to spoilage, and thus had a shorter shelf-life. It is noteworthy that, short shelf-life would affect smoked fish accessibility to the remote resource-poor population, who depend on this cheap product for essential nutrients (Adeyeye \& Oyewole, 2016). Additionally, spoilage certainly affects socio-economic life of communities involved in artisan smoking sector, and the retailers involved smoked fish selling. In light of this, re-smoking to keep microbial numbers low, serves as a viable alternative for prolonging the shelf-life of hot-smoked fish "Muwotokwa" while on shelf.

From the study, both spoilage and pathogenic indicator organisms were isolated from fish samples and these included; S. aureus, Coliforms, E. coli, Fungi and generally mesophilic aerobic bacteria. Most of these are from soil, human, animals and untreated water (FAO, 1992; Ali et al., 2011; Tegule, 2011). One of the important assays routinely used to predict the microbiological quality of foods is the enumeration of aerobic bactaria, and this is determined using aerobic plate count (APC) or total plate count (TPC) method (Diez-Gonzalez, 2014). Hence, the TPC was done to obtain a rough indication of microbiological quality of fish traditionally smoked from Uganda. Furthermore, the acceptable TPC load in fresh fish does not exceed $10^{7} \mathrm{cfu} / \mathrm{g}$ (ICMSF, 1986), but from this study, all fresh fish samples examined had aerobic mesophilic bacterial load above this value. This indicated poor microbiological quality of fresh fish from the processing sites. The high load was probably due to temperature abuse, poor personal hygiene, as well as water and equipment contamination. Although smoking process significantly reduced aerobic mesophilic bacteria, their numbers in freshly smoked fish $(>7 \log \mathrm{cfu} / \mathrm{g})$, was still higher than the recommended $<4 \log \mathrm{cfu} / \mathrm{g}$ (Gibert et al., 2000). Our findings did not agree with the aerobic mesophilic bacteria load reported in Sudan (Egbal et al., 2010), where zero counts for the same organisms was obtained. This was probably due to the differences in smoking technology and fish handling as well as initial microbial load in fresh samples before smoking. Similiraly, our findings revealed slightly higher load than those reported in Ghana and Nigerian markets (Arthur \& Osei-Somuah, 2004; Abolagba et al., 2011). In addition, TPC for smoked fish obtained from markets was also more than the acceptable limits. The TPC status, indicated poor handling conditions, which required urgent attention from fish handlers and food quality agencies.

Furthemore, coliforms are among the indicator organisms whose presence especially in high numbers indicate a possibility of pathogenic organisms being present (FAO, 1992). Accrodingly, coliforms were present in fresh fish samples from all landing sites with mean counts of over two fold above the acceptable limits $(230 \mathrm{cfu} / 100 \mathrm{~g})$ by ICMSF, (1986). Essentially, the presence of high coliform load in fresh fish, is indicative of environmental contamination or pollution (ICMSF, 1986). Previously, a high load of coliforms (5 log of cfu/g) in water samples from Lake Victoria was reported, and this was attributed to industrial and domestic waste contamination (Tegule, 2011). In light of this, the differences in levels of total colifom load revealed by the study, could have been attributed to the varying levels of water contamination from different parts of the Lake and the general poor handing by fish handles. Findings from a study conducted in Nigeria showed even higher coliforms count in fresh fish ranging from 7-8 log of cfu/g (Adebayo-Tayo et al., 2012). Despite the high total coliform counts in fresh fish, traditional smoking process significantly $(\mathrm{P}<0.05)$ reduced coliforms to acceptable levels (Gilbert et al., 2000), except for samples from Kasenyi landing site. The sensitivity of organisms to heating (Tzouros \& Arvanitoyannis, 
2000), could have been responsible for reduction of coliforms. Nevertheless, as indicators of hygiene and contamination (Gilbert et al., 2000), high coliform load for Kasenyi samples indicated a likelihood of poor handling during smoking although the initial load in fresh samples could have also contributed. Furthermore, while the colofrm load was within acceptable range for on shelf smoked fish, those from Bwaise market was not (Gilbert et al., 2000). This pointed to re-contamination probably attributed to poor fish handling.

One of the most important members of coliforms is E. coli, and perhaps this is the most preferred indicator organism for contamination and mishandling of fish (FAO, 1992). In this study, presence of E. coli was investigated as measure for sanitary and health hazard monitoring. Accordingly, presence of higher E. coli levels about five fold more than acceptable $2 \mathrm{cfu} / \mathrm{g}$ (ICMSF, 1986), pointed to a possibility of fecal contamination from water and the fish handlers. This could have been fueled by increasing human settlement near the lake, lacking latrines but also being involved in activities generating industrial wastes that end up in the lake. Contamination of lake water with E.coli was reported in a study by Tegule, (2011). Consumption of fish contaminated with this organism leads to gastroenteritis manifested oftenly diarrhoea (Lopes da Silva et al., 2010), the severity however depends on strain ingested. In spite of the presence of $E$. coli in fresh fish, the study showed that, traditional smoking process destroyed the organisms to acceptable levels (Gilbert et al., 2000). The destruction was attributed to high sensitivity to heating during hot-smoking. Similar significant $E$. coli reductions were also reported in Cameroon (Ali et al., 2011) and Sudan (Egbal et al., 2013). While smoking eliminated E. coli, the study revealed very high mean microbial load for on shelf smoked fish from markets except for Nakulabye. This evidently indicated re-contamination with fecal matter, which was a pointer for poor handling conditions. Furthermore, the presence of similar E.coli numbers was also reported in Ghana (Arthur \& Somuah, 2004). In view of these findings, on shelf smoked fish from markets in Uganda, presented a potential health hazard to consumers more so for those who don't reheat or cook smoked fish before consumption.

From the study, mean microbial counts for $S$. aureus in fresh fish with exception of Katosi samples, were higher than routinely accepted levels $\left(<10^{5} \mathrm{cfu} / \mathrm{g}\right)$ according to Lopes da Silva et al., (2010). Presence of such high numbers indicated poor handling conditions among fish handlers. This is regard of the fact that majority $(80 \%)$ of S. aureus organisms are harbored by humans as normal flora (FAO, 1992; Adebayo-Tayo et al., 2012). Furthemore, while low numbers in raw fish are not a concern, very high $S$. aureus load can be hazardous (Adebayo-Tayo et al., 2012), because $S$. aureus potentially elaborate an enteroxin that is heat stable. In view of thism prevention of higher numbers of $S$. aureus in food is a safer option, because the toxin can not be destroyed by heating. In contrast, the lower numbers reported in the previous study from Brazil (Lopez da Silva et al., 2010), indicated that, S. aureus load can be reduced through improved sanitary conditions. Nonetheless, the heating process that provides internal temperature of above $65.5^{\circ} \mathrm{C}$ for 30 minutes readily destroys $S$. aureus (FAO, 1992; Tzouros \& Arvanitoyannis, 2000). Accordingly, hot-smoking process eliminated $S$ aureus in all samples from Ggaba and Katosi, except for Kasenyi smples. Presence of higher load $>3 \mathrm{log} \mathrm{cfu} / \mathrm{g}$ than acceptable load of $<2 \mathrm{cfu} / \mathrm{g}$ (ICMSF, 1986) in freshly smoked fish, necessitated proper re-heating of smoked fish before consumption but also shortening of its shelf-life to avoid further proliferation of the organisms. Furthermore, the presence of what is described as unsatisfactory (Gilbert et al., 2000) numbers in samples from Kasenyi was probably attributed to higher initial numbers in fresh fish or re-contamination during smoking process. While hot-smoking process reduced $S$. aureus load to acceptable levels, the presence of very high numbers more than acceptable $(<2 \log \mathrm{cfu} / \mathrm{g})(\mathrm{ICMSF}, 1986)$ in samples obtained from the market, revealed a high possiblity of recontamination. Based on study findings, it was also generally deduced that, smoked fish sold from Kampala markets were potentially hazardous to cconsumers.

Apart from bacteria, mycoflora including Yeasts and molds, have been used as indicators for microbiological quality of food or fish. This is so because, a number of mycoflora species are responsible for spoilage of different foods including fish, smoked or fresh. Whereas some species are useful in fermentation and ripening of some foods, others clearly cause spoilage of foods (Lorenzo et al., 2018), hence, they can be used to indicate possibility of fish spoilage. According to the study, low fungal counts (4 log of $\mathrm{cfu} / \mathrm{g}$ ) were found in fresh samples, probably due to, high moisture content and may be fish habitat did not favor their proliferation. This is because, mycoflora require low water of activity for their proliferation and therefore, most species prefer growing on dried products (Ali et al., 2011). Furthermore, the traditional smoking process significantly $(\mathrm{P}<0.05)$ reduced these organisms for Katosi and Kasenyi, except for the samples from Ggaba. The variation in mycofloral destruction was probably due to presence of different fungal species in fish. Regardless, in spite of the low numbers in fresh samples, generally heating did not eliminate all organisms from all the samples, in this case the role of spore formation known to considerably resist destruction by heating could not be underestimated. Nevertheless, while freshly smoked fish had low numbers, those from Bwaise still presented a potential quality concerns since their levels $(4 \log$ of cfu/g) were not within acceptable range. Therefore, on shelf smoked fish from Bwaise presented quality concerns and also a health hazard to consumers. The latter was particularly crucial considering their potential to elaborate mycotoxins elaboration. By and large, much as prolonged smoking with salting $(5 \%)$ is encouraged for control of fungal growth (Omojowo et al., 2010), periodic re-smoking pending fish sale could also be a viable alternative. 


\section{Conclusion}

Fresh fish generally harbored unacceptably high microbial numbers for various indicator organisms. However, traditional smoking process reduced, and for some samples eliminated most microbes to acceptable levels, and this indicated considerable level of effectiveness. It is noteworthy that, while smoking process considerably destroyed the microbes, moisture content left in freshly smoked fish was still very high, and this indicated a relatively short shelf-life of traditionally smoked fish in Uganda. The presumed short shelf-life was deemed disadvantageous to the smoked fish consumers in remote areas, since accessibility before quality loss was not guaranteed. Furthermore, although smoking significantly reduced all microbes investigated, fish re-contamination post-smoking due to poor handling conditions, was found to offset the usefulness of the widely used traditional smoking method. In view of this, much as freshly smoked fish was of good microbiological quality and fit for consumption, the same could not be said for smoked fish from the markets. Therefore, for assured smoked fish quality in Uganda, we recommend that; traditional fish smoking in Uganda be improved through; proper food handling awareness and training, use of improved kilns, and improved hygiene before, during and after smoking. Additionally, re-smoking of smoked fish before sale, holding of smoked fish for shorter time before sale, regular fish inspection, and proper cooking of on shelf smoked fish before consumption, are highly recommended.

\section{Acknowledgement}

The authors wish to thank the European Union through Edulink, and Dr. David Kaahwa, Department of Wildlife and Aquatic Resources, Makerere University for the financial and academic support rendered without which, little would have been achieved.

\section{References}

Abigaba, R., Nakavuma, L. J., Kankya, C., \& Kaahwa, D. (2020). Traditional Fish Smoking Among Artisan Processors in Lake Victoria Crescent, Uganda. International Journal of Agriculture, Forestry and Fisheries, 8(4), 109-117.

Abolagba, O. J., Adekunle, A. T., Dede, A. P. O., \& Omoigui, G. O. (2011). Microbial assessment of smoked fish (Clarias spp) in Benin Metropolis, Edo State, Nigeria. Nigerian Journal of Agriculture, Food and Environment, 7(3), 55-58.

Abolagba, O.J. \& Uwagbai, E.C., (2011). A Comparative Analysis of the Microbial Load of Smoked-dried Fishes (Ethmalosa Fambriata and Pseudotolithus Elongatus) Sold in Oba and Koko Markets in Edo and Delta States, Nigeria at different Seasons, Australian Journal of Basic \& Applied Sciences, 5(5), 544-550.

Adebayo-Tayo, B. C., Odu, N. N., \& Okonko, I. O. (2012). Microbiological and physiochemical changes and its correlation with quality indices of tilapia fish (Oreochromis niloticus) sold in Itu and Uyo markets in Akwa Ibom State, Nigeria. New York Science Journal, 5(4), 38-45.

Adeyeye, S. A. O. \& Oyewole, O. B. (2016). An Over of Fish Traditional Smoking in Africa. Journal of Culinary Science \& Technology, 14(3), 198-215.

Ali, A., Ahmadou, D., Bouba, A. M., Saidou, C., \& Tenin, D. (2011). Influence of Traditional Drying and Smoke Drying on the Quality of the three fish species (Tilapia nilotica, Silurus glanis and Arius parkii) from Lagdo Lake, Cameroun. Journal of Animal and Veterinary Sciences, 10(3), 301-306.

Arthur, C. T., \& Osei-Somuah, A. (2004). Microbiological Contamination of Smoked Anchovis. Ghana Journal of Agricultural of Science, 37, 69-74.

Diez-Gonzalez, F. (2014). Total Viable Counts: Specific Techniques. In C. A. Batt \& M. L. Tortorello (Eds.) Encyclopedia of Food Microbiology, 3 Academic Press, 630-635.

Egbal, O. A., Mohammed, E. A., Regiah, A. K., Hana, M. T., \& Asgad, A. M. (2010). Investigating the quality changes of raw and hot smoked Oreochromis niloticus and Clarias lazera Pakistan Journal of Nutrition, 9(5), 481-484.

FAO. (1992). Manuals of food quality control, 4. Rev.1. Microbiological analysis. Food and Nutrition Paper. Rome: Food and Agricultural Organization of the United Nations.

FAO/WHO. (2004). FAO/WHO guidance to governments on the application of HACCP in small and/or lessdeveloped food businesses Paper presented at the FAO/WHO Technical Meeting on the Application of the Hazard Analysis Critical Control Point (HACCP) System in Small and/or Less Developed Businesses (SLDBs), Rome, Italy.

FAO/WHO. (2011). Report of the Joint FAO/WHO Expert Consultation on the Risks and Benefits of Fish Consumption FAO Fisheries and Aquaculture (pp. 33). Rome, Italy.

Gilbert, R. J., Louvois, D. J., Donovan, T., Little, C., Nye, K., Ribeiro, C. D., . . Bolton, F. J. (2000). Guidelines for the microbiological quality of some ready-to-eat foods sampled at the point of sale. Communicable Disease and Public health, 3(3), 163-167.

ICMSF. (1978). Micro-organisms in foods (1) their significance and methods of enumeration ( $2^{\text {nd }}$ edition). University of Toronto Press: Blackwell Scientific Publications. 
ICMSF. (1986). Microorganisms in Foods 2. Sampling for microbiological analysis: Principles and specific applications. ( ${ }^{\text {nd }}$ Edition). University of Toronto Press, Toronto: Blackwell Scientific Publications.

Kabahenda, M. K., Omony, P., \& Hüsken, S. M. C. (2009). Post-harvest handling of low-value fish products and threats to nutritional quality: a review of practices in the Lake Victoria region. Fisheries and HIV/AIDS in Africa: Investing in Sustainable Solutions. The WorldFish Center: FAO.

Kleter, G. A. (2004). Control and prevention of contamination and spoilage in the traditional production of smoked fish in Ghana (pp. 7-19). The Netherlands RIKILT - Institute of Food Safety.

Kumolu-Johnson, C. A., Aladetohun, N. F., \& Ndimele, P. E. (2010). The effects of smoking on the nutritional qualities and shelf-life of Clarias gariepinus (BURCHELL 1822). African Journal of Biotechnology, 9(1), 073-076.

Lopes da-Silva, L. M., Matté, R. G., Germano, L. M. P., \& Matté, H. M. (2010). Occurrence of pathogenic microorganisms in fish sold in São Paulo, Brazil. Journal of Food Safety, 30, 94-110.

Njiru, M., Kazungu, C., Ngugi, C. C., Gichuki, J., \& Muhoozi, L. (2008). An Overview of the Current Status of Lake Victoria Fishery: Opportunities, Challenges and Management Strategies. Lakes \& Reservoirs: Research and Management, 13, 1-12

Olaleye, O.N. \& Abegunde, T. A., (2015). Microbial Safety Assessment of Selected Smoked Fish in Lagos Metropolis, British Microbiology Research Journal, 9(3), 1-5.

Omojowo, F. S., Omojasola, P. F., Kolawole, M. O., Ngwu, E. O., Oluborode, G. B., \& Adetunji, C. O. (2010). Effect on brining on the microbial quality and safety of smoked catfish. New York Science Journal 3(6), 2026.

Plahar, A. W., Nerquaye-Tetteh, A. G., \& Nana, T. A. (1999). Development of an integrated quality. assurance system for the traditional Sardinella sp. and anchovy fish smoking industry in Ghana. Food Control, 10, 1525.

Salaudeen, M. M. \& Osibona, A. O., (2018). Impact of Smoking Techniques and Storage Conditions on Microbial Safety and Stability of Catfish (Clarias gariepinus). Ife Journal of Science, 20(2), 345-353

Swastawati, F. (2008). Quality and Safety of Smoked Catfish (Aries talassinus) Using Paddy Chaff and Coconut Shell Liquid Smoke Journal of Coastal Development, 2(1), 47-55.

Tegule, S. S. (2011). Assessment of Bacterial Contamination and Antibiogram of Selected Pathogens Isolated from Lake Victoria Water and Fish (Oreochromis niloticus) Around Jinja Municipality. (Master of Science Thesis), Makerere University, Uganda.

Tzouros, N. E., \& Arvanitoyannis, I. S. (2000). Implementation of Hazard Analysis Critical Control Point (HACCP) System to the fish/seafood Industry: A review. Food Reviews International, 16(3), 273-325.

Harrigan, W. (1998). Laboratory Methods in Food Microbiology. (3 ${ }^{\text {rd }}$ Edition), Academic Press., pp: 532

UIA. (2009). Fisheries Sector Brief: Uganda Investiment Authority (19.002/Qlt/Fisheries Sector). KampalaUganda: Retrieved from; www.ugandainvest.go.ug on June 15, 2017. 